7. of Modern African Studies, 40, I (2002), pp. I33-157. (C) 200 I Cambridge University Press DOI : I0.1017/Soo22278Xoroo3846 Printed in the United Kingdom

\title{
Being taken for a ride: privatisation of the Dar es Salaam transport system 1983-1998
}

\author{
Matteo Rizzo*
}

\begin{abstract}
A B S T R A C T
This paper analyses the effects of privatisation and deregulation of the Dar es Salaam transport system. It starts with an account of the decline of the government-owned transport company and the first opening of the market to private buses in 1983 . The analysis then moves to the progressive deregulation of the sector and its impact on transport supply. Competition between private operators in the oversupplied market manifests itself in noncompliance with safety rules, and inefficiencies in the fare structures. Labour relations with the private sector are then examined to illustrate the logic of the market. The results of a questionnaire answered by 668 workers suggest that the reaction of casual workers to exploitative conditions of employment characterises many aspects of the operation of the transport system. The impact of deregulation is therefore most clearly to be seen in the nature of labour relations within the sector, and it is argued that there is a need for state regulation to monitor and enforce conditions of employment within the private sector if service provision is to be improved.
\end{abstract}

\section{N T R O D U G T I O N}

Since the international financial institutions first identified privatisation as a condition for assistance to developing countries, in the early i 980 , the economic role of the state in central planning and regulation has been in steady decline throughout sub-Saharan Africa (SSA). So pervasive are the goals generally associated with privatisation that it has been labelled an omnia ad omnes (all things to all men) policy (Adam et al. I 992:3). The principal benefits that privatisation is intended to bring about include the reduction of state fiscal deficits by the sale of loss-making parastatals, the broadening of the ownership of economic assets, increased productivity and improved efficiencies in

\footnotetext{
* Doctoral candidate, SOAS, University of London. Thanks go to David Anderson, Maria Cristina Ercolessi, John Sender and two anonymous referees for comments on earlier drafts of this paper.
} 
redistribution. Above all, the ideological underpinning of privatisation is the belief that, in the shift from public to private management, the economy will benefit from the superior economic performance of the private sector. Yet, despite the importance of privatisation in current economic policies in SSA, a feature of the literature on its implementation is the consensus on how little we know about its actual impact and functioning (Bennell ı997: г785; Berg ı996: 6; Cramer 2000: 93). Part of the problem of evaluation is due to the fact that the belief in the superior efficiency of the private sector has become 'almost axiomatic' (Adam et al. i992: 3). Even the International Monetary Fund (IMF) has struggled to assess the effects of privatisation, in one of its reports on Tanzania providing evidence of 'considerable progress with privatisation' in the fact that state involvement had been removed from almost $60 \%$ of approximately 400 parastatal bodies by mid I 998 (IMF i 999: I 5), but at the same time admitting that for only one of these privatised companies was post-privatisation information available on economic performance. The emphasis upon the change of ownership, without reference to post-privatisation performance, thus turns privatisation from a means to an end in itself. In short, while we know that privatisation is taking place, we remain very unsure of its economic impacts.

A consensus is now emerging that privatisation does not necessarily result in the creation of a vibrant private sector characterised by the growth-enhancing competition that many had hoped for. With the acknowledgement in a recent World Bank sponsored report, that 'competition is more important than privatisation per se' (Campbell White \& Bhatia I998: 24), the state would seem to be creeping back into the debate. Some commentators argue that state regulation might be necessary where social and private costs and benefits do not coincide, to offset the outcomes of perverse competition, and to ensure that a firm acts in a manner consistent with social welfare (Adam et al. I 992: I9). For example, in the case of the privatisation of the processing and manufacturing of vegetable oils in Tanzania, Temu and Due (2000: 697) have found that whilst short-term profit maximisation was achieved through the import of cheaper oils, this in fact hindered the national economy through the loss of evaded taxes from imported processed oil, a lowering of demand for locally grown raw materials, and diminished employment opportunities for local people. Whilst such examples serve to highlight the ambiguities of the economic impacts involved, there remains a need for the rigorous assessment of the effects of privatisation. In this respect, market structures, the reactions of the 
TABLE I

Public buses in service r $974^{-1998}$

\begin{tabular}{|c|c|c|c|}
\hline Year & Operating buses & Year & Operating buses \\
\hline I 974 & I 30 & I $986 / 87$ & IO I \\
\hline I 975 & 257 & I $987 / 88$ & Iog \\
\hline I 976 & 245 & I $988 / 89$ & 70 \\
\hline I $977 / 78$ & $22 \mathrm{I}$ & I $989 / 90$ & 59 \\
\hline I $978 / 79$ & I 72 & I 990/9 I & $3^{2}$ \\
\hline I $979 / 80$ & I 42 & I 99 I / 92 & 25 \\
\hline I980/8I & I 4 I & I 992/93 & $3^{6}$ \\
\hline I 98 I / 82 & I 39 & I 993/94 & 54 \\
\hline I $982 / 83$ & I 64 & I $994 / 95$ & $4^{\circ}$ \\
\hline I $983 / 84$ & I 4 I & I $995 / 96$ & $3^{2}$ \\
\hline I $984 / 85$ & I 39 & I $996 / 97$ & 24 \\
\hline I $985 / 86$ & I08 & I $997 / 98$ & I 2 \\
\hline
\end{tabular}

Sources: Shirika la Usafiri Dar es Salaam i995: 6; Shirika la Usafiri Dar es Salaam (UDA), 'Fleet performance files' (I994/95-1997/98).

various actors within the sector, and the design of a set of rules seeking to direct actors towards the desired functioning of the market, are all features of the transition that must be closely examined. In any example of privatisation, political choices must be made and these are likely to be contingent upon the reactions - and perceptions of the likely reactions - of the actors involved.

This paper analyses these dynamics and the effects of privatisation for the deregulation of the Dar es Salaam transport system-the operation of the city's buses, or daladala. ${ }^{1}$ The first section describes the initial regulatory framework of the system under the monopoly regime up to 1983 and the dismal performance of the public transport company up to that date. The next section analyses the progressive deregulation of the sector and its impact on the supply side. The third section evaluates the performance of the private sector. Increased competition, resulting from the oversupply of the market, is suggested as the most distinctive feature of the transition, to be seen in the deepening exploitation of casual workers, increasingly pervasive noncompliance with safety rules, and continued conflict between tariffprotected student travellers and bus workers. In the final section, the activities and role of the association of bus owners is outlined for this period of transition. ${ }^{2}$ 
THE MONOPOLY OF THE STATE (I970-I983)

With the Arusha Declaration of 1967 , the government of Tanzania embarked upon the ujamaa socialist strategy of development. A highly interventionist state placed itself at the centre of the development agenda. Whole sectors of the economy were nationalised, and in 1970 this process was applied to the transport system with the nationalisation of the Dar es Salaam Motor Transport Company (DMT), a British private company that had operated under a monopoly regime since i947 (Mamuya i993: ro8). In r974, the nationalised company was divided into two: the Kampuni ya Mabasi ya Taifa (KAMATA) became responsible for inter-regional routes, while the Shirika la Usafiri Dar es Salaam (UDA) was granted 'an exclusive licence to operate public omnibuses in Dar es Salaam' (URT r 974). From the very beginning, the performance of the nationalised public transport company was disappointing. The dramatic decline is fully documented in Table I, showing a steady decrease in the number of buses operated by the company, from 257 in 1975 to only 12 in 1998 . This amounted to a crisis of public transport, which in many respects mirrored the harsh economic conditions experienced by the Tanzanian state since the midI 970s. Recurrent shortfalls in government funding made available to UDA - which from 1974 to 1983 received only $35 \%$ of the foreign exchange funds it had requested from central government (Stren i 989: 52) - indicate the crisis but do not establish its cause. As foreign exchange became a scarce resource, parastatals competing for shrinking government funding responded by pushing up their annual funding estimates, in an attempt to minimise the effect of inevitable government cuts against the budget. Nonetheless, the government's foreign exchange shortage certainly played a role in the UDA crisis. But other factors relating to the constraints placed upon the company were perhaps of greater significance. Although UDA was formally expected to operate on a commercial basis (URT i 974), government in fact privileged the welfare function of public transport by keeping tariffs low and subsidising the company (Mamuya i993: iro). As the economic situation worsened, the shortage of foreign exchange made it impossible to purchase the number of buses necessary to match the increasing demand for transport; at the same time, a lack of imported spare parts delayed the repair of the existing fleet and slowly took its toll on service provision. ${ }^{3}$ Poor public management of existing resources was also a factor behind the crisis. Under-qualified personnel and absenteeism are mentioned by UDA as causes of its difficulties by the 
PRIVATISATION OF DAR ES SALAAM TRANSPORT SYSTEM I 37

early ig9os (UDA I 994: 3 I-2). Furthermore, if one considers that the average operating life of buses in service was shortened by the deterioration of an inadequately financed urban road system from the I 970 o to the I99os, ${ }^{4}$ then the complex set of causes behind Tanzania's public transport crisis become clearer.

While transport supply was in decline, demand was rising. In I967, Dar es Salaam had a population of 273 , ooo. According to the National Census, by 1978 this figure had nearly tripled to 769 ,000 (O'Connor I988: 1 36), and in 1988 the Population Census (Bureau of Statistics I989) recorded the city as being home to some I,360,850 residents. Government was slow to respond to the increased demand that these figures implied. From 1972 to I 974, the government did briefly tolerate the activities of private operators alongside the public company, but in I 975 such operators were banned (Stren i 989: 52). Opposition to the private sector was at this time deeply embedded in the ideology of the Tanzanian government. In a country whose leadership had set a classless society as the final goal of the development strategy, a highly progressive tax system and frequent increases in minimum wages were the policies adopted to reduce the income disparity amongst the formal sector workers. Yet Tanzania managed to substantially reduce the gap between the maximum and minimum wage, whose ratio fell from $\mathrm{I}: 5^{\circ}$ in I96 I to I:7 in the early ig8os (Maliyamkono \& Bagachwa r990: 30). From this perspective it is possible to understand why the informal economy - where profits and wages were not subject to the state's redistributing action - was perceived by the authorities as a locus where individuals could profit at the expense of others and therefore as a threat to the establishment of a more egalitarian society. However, the government's adoption of policies that penalised activities within the private sector, maintained until the mid-ig8os, ran alongside the decline of state economic capacity. As Mamuya (I993: I I I) has calculated, by the time that private operators were again allowed opportunities in transport service provision, UDA could satisfy only about $60 \%$ of the total demand.

THE ROAD TO MARKET REFORM (I 983 -I 998 )

In I983, transport service provision was opened to private operators. This step was taken alongside new initiatives designed to strengthen the public transport supply. The government issued a directive requiring all ministries, government departments and parastatals to use their 
staff buses as commercial public passenger buses (Mamuya i 993: I i I). As a consequence of the directive, 6 I buses belonging to 27 parastatals began to co-operate with the I4 I operational buses of the public company (Daily Newes 3 I.3. I 983). In the private sector, the government removed import restrictions and delegated the registration of private operators to a committee in which the Ministry for Communication and Transport, UDA and the National Transport Corporation were each represented. Two aspects of the registration procedures have to be stressed in order to understand the political climate in which the reform took place. First, UDA was given sole authority to legally register all private operators. Applications had to be presented to a section in the Ministry for Communication and Transport, and then forwarded to UDA for selection. To obtain a licence, private operators had first to satisfy the safety requirements of the Traffic Police department. Successful applicants were then allocated a route that they were allowed to operate as sub-contractors of the UDA, for which they paid UDA a monthly fee. These arrangements were defined in the contract held by the UDA (URT I974: 2). Second, the government also retained the power to set fares. Since the UDA licence stated that "the fares to be charged by the Company shall not exceed those approved by the government or any other authority responsible for setting fare rates' (URT I974: 2), private operators, as sub-contractors of the UDA licence, were also compelled to operate at tariffs set by the authority concerned.

These modalities of regulation reveal that the initial opening to private operators of the Dar es Salaam transport system took place without a substantial revision of the ideological underpinning of the monopoly formerly held by the state. The public transport company formally maintained its monopoly, while sub-contractors were conceded monthly licences, leaving the government with the opportunity to restore the monopoly at notice of no more than one month. It therefore seems that the government at this stage saw the private sector only as a means towards a temporary easing of the shortage of transport supply, and not as a long-term structural change of public transport policy. The ambiguities of this policy shift are apparent in the statements made in a document published by the Ministry for Communication and Transport (MCT I987:49-50) four years later. First, in clear and apparently unequivocal terms the Ministry stated that 'whatever the combination of polices adopted in each town, public transport (rather than private transport) will be essential', going on to explain that 'ideally, public transport, and in this case the bus, is and 
TABLE 2

Trends in registered private buses 1983 - I99 I

\begin{tabular}{lc}
\hline \hline Year & Buses \\
\hline I983 & I 78 \\
1984 & 271 \\
1985 & 294 \\
1986 & 300 \\
1987 & 300 \\
1988 & 300 \\
1989 & 175 \\
I990 & 175 \\
I991 (March) & 355 \\
\hline \hline
\end{tabular}

Source: Shirika la Usafiri Dar es Salaam i 994: 26.

will always be considered more efficient than private transport'. However, when discussing the specific case of Dar es Salaam, the same document more pragmatically conceded that 'other operators, including private operators, can also be incorporated, but under the coordination of one institution' (ibid.: $5^{\mathrm{O}-\mathrm{I}}$ ). Privatisation in transport was only to operate under parastatal control, it seemed, and this only within the city of Dar es Salaam.

The Tanzanian government therefore initially reacted to external (IFI) and internal pressures for reform by restating the state's entitlement to continue to dominate access to the sector and to define the modalities for companies applying for licences to provide transport services. Initially, the response of private operators to this new investment opportunity was modest. Official figures show that the number of registered buses fluctuated for the period from I 983 to I 990. In I 983 , there were 178 private buses in service. By I985 this had climbed to 294, only to fall back again to I 75 in I 989 . The first buses to be registered under the UDA's new sub-contracted licences in Dar es Salaam city had previously been operating on up-country routes. The Dar es Salaam transport system represented a potentially lucrative market for these operators, but despite this the number of daladala ${ }^{5}$ did not continue to increase. The main factor discouraging the registration of private operators was that government tariff policy continued to protect low-income groups, rather than fostering private profit. As is shown in Table 3, although fares registered a $600 \%$ increase from I 983 to $\mathrm{I} 99 \mathrm{I}$, in the same period the domestic currency experienced a devaluation of $1,836 \%$. As buses and spare parts were necessarily 
TABLE 3

Tariffs and devaluation trends I983-I99 I

\begin{tabular}{|c|c|c|c|c|c|c|c|c|c|}
\hline Year & I 983 & I 984 & I 985 & I 986 & 1987 & I 988 & І 989 & I990 & I 99 I \\
\hline Tshs/US\$ & I 6.34 & $\mathrm{I} 7.2 \mathrm{I}$ & 38.16 & 68.65 & I 08.25 & I 54.68 & I 97.00 & 230.00 & 300.00 \\
\hline Tariff (Tshs) & 5 & 5 & 5 & 6 & 6 & 8 & I 5 & I 5 & I 5 \\
\hline Tariff (US\$) & $0.3 \mathrm{I}$ & 0.29 & o.I3 & 0.087 & 0.055 & $0.05^{2}$ & 0.076 & 0.065 & o. Io \\
\hline
\end{tabular}

Source: Shirika la Usafiri Dar es Salaam i994: 22-3.

purchased with foreign currency, the devaluation severely hampered any private entrepreneurs seeking to enter the daladala business. Hence, it was only those operating existing buses on alternative routes who were at first able to take advantage of the government's limited steps towards reform. Moreover, existing ownership patterns seem to have had some impact upon trends in registration. According data from the Ministry for Communication and Transport for i 989, a large majority of operators owned only one bus. Only two entrepreneurs owned two buses, and only one operator had more than five buses (Mamuya i 993 : I I3). As a consequence, there were very few owners who were capable of increasing their fleet from a business-generated capital base.

The next step in the gradual process of reform came in the period I990-9 I, when it seems that changes in national policy had an impact upon the daladala sector in Dar es Salaam. In i 989 , the final tranche of the i $986-89$ structural adjustment programme agreed by Tanzania and the IMF was initially withheld on the grounds that liberalisation policy had to be 'faster and steeper' (Baregu i 993: II I). The government responded to this threat with the adoption of the Investment Promotion and Protection Act in 1990. For investors this Act meant, amongst other things, full exemption from import taxes, and a five-year exemption from tax for newly established businesses (ibid.: I I I). The Act was accompanied within the Dar es Salaam transport system by the adoption of a more profit-oriented tariff policy, and by the abolition of state control on the number of licences issued to private operators. Over the period from i 99 I to i 996 , daladala tariffs increased fivefold, whilst the domestic currency experienced a devaluation of only about $100 \%$. The powerful effect of this new tariff policy on private operators registration was confirmed by the general manager of UDA, Kushoka, who reported that the number of daladala trebled in the first six months after the doubling of fares in February 
PRIVATISATION OF DAR ES SALAAM TRANSPORT SYSTEMI4I

TAвLE 4

Trends in registered private buses I99 I-I999

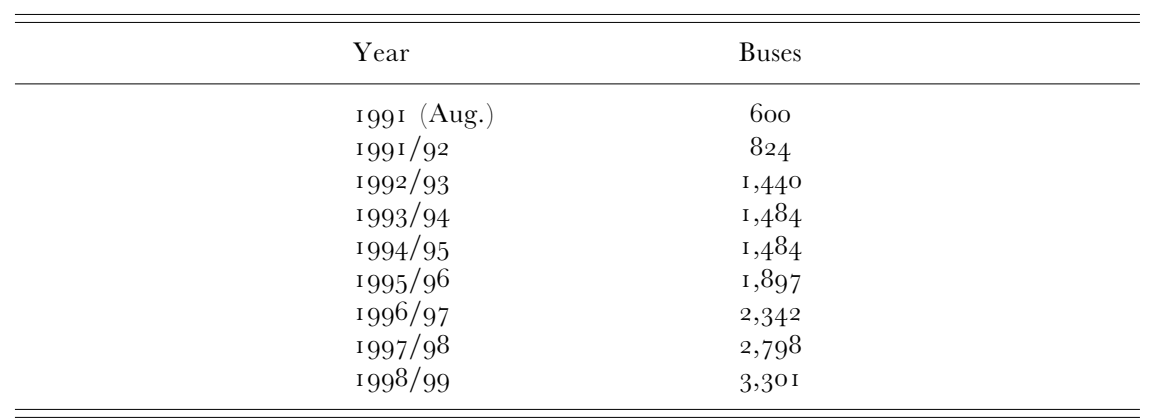

Source: Shirika la Usafiri Dar es Salaam 1994: 27; Central Transport Licensing Authority, 'Microbuses Files', (1994-98).

TABLE 5

Tariffs and devaluation trends I99 I-I 996

\begin{tabular}{|c|c|c|c|c|c|}
\hline Date of tariff review & $3.2 .9 \mathrm{I}$ & I I .2 .93 & 9. I0.93 & 7.I.95 & 20. I 2.96 \\
\hline Tshs /US\$ & 300 & 437 & $53^{\circ}$ & 574 & 580 \\
\hline Tariff (Tshs) & $3^{\circ}$ & $5^{\circ}$ & 70 & IOO & I 50 \\
\hline Tariff (US\$) & o. Io & O.I I 4 & o.I $3^{2}$ & o. I 74 & $0.25^{8}$ \\
\hline
\end{tabular}

Sources: Shirika la Usafiri Dar es Salaam i 994: 24; Africa South of Sahara 1999; Daily Neres 8. I. 1995 , 3.1.12.1996.

i99 (Daily News 25.I I.r99I). With regard to state control on the licensing of private daladala operators, in I99 I UDA was relieved of its authority to sub-contract licences. The GTLA then became the only agency responsible for handling registration applications (UDA I994: 28), but had no powers to reject any application except on the basis of non-compliance with roadworthiness rules.

The shift towards a free market regime in the Dar es Salaam transport system was subsequently completed by the progressive deregulation of the tariff mechanism. The transition to a supply and demand driven fare system began in 1996, the year in which the general secretary in the Ministry for Communication and Transport publicised that whilst transport operators could not charge fares above the fixed fare, they could charge less (Daily News 3 I.I2.I 996), and was completed in 1997 when the minister declared that bus fares would in 
future be determined solely by market forces (Daily News 25.7.1997). These tremendous policy changes account for a dramatic increase in the number of registered daladala from 600 in I 99 I to 3,30 I in I 998 . By the end of the i $990 \mathrm{os}$, the Dar es Salaam passenger transport system was almost entirely supplied by private operators under a free market regime. Indeed, privatisation had gone so far that many people in the city now fail to realise that the state-run UDA is still in operation. As one of its officials lamented (Mlaki i998):

Amongst Traffic Police agents, the younger ones do not know what the UDA is, as nowadays we have very few buses. One day they rang me from the Police Central Station because one of our buses had been stopped by a young agent who believed it was a pirate daladala operating without licence. I had to go the Station to explain to him that we are UDA, that we have a licence allowing us to operate in all areas of Dar es Salaam, and that at one time we were the only supplier on the market.

THE EFFEGTS OF DEREGULATION

Moving to an assessment of deregulation, the first question to ask concerns the extent to which daladala operators are in fact complying with the new system of licensing. With the liberalisation of state controls on daladala operation, it might reasonably be expected that more private operators would be encouraged to participate in the licensing scheme and that the numbers of 'pirate buses' would decline. However, it is apparent that a large proportion of private operators still supply the market without a licence, despite deregulation. There are no reliable regular statistics on the exact numbers of pirate operators, but two surveys conducted at the beginning of the r 990 os suggest that there were then about as many unlicensed operators as those with licences: in 1990 it was estimated that there were 202 unregistered daladala operators, and 175 registered; in I99I, the figures were calculated as 338 unregistered and 355 registered operators (UDA r 994: $26-7$ ) ${ }^{6}$ A more recent estimate, made by the president of the daladala owners' association, suggests that there are as many as 7,648 daladala in operation (Ndaombwa I998). An article published in The East African during ig99 provided an estimate of ' 6,300 plus' buses. ${ }^{7}$ Both these estimates again suggest that the numbers of unlicensed buses remains close to the number officially registered, at somewhere between 3,000 and 4 ,ooo.

While this general impression is probably a fair reflection of the situation, it must be acknowledged that monitoring of supply in the 
market is far from precise. My own survey of the data of three different institutions concerned with the operation of private buses shows that there is no consistent figure for the number of compliant private operators. Data was collected in 1998 on daladala registered with the City Commission (to which private operators have to pay a fee for the maintenance of the road system), with the Tanzania Revenue Authority (to which operators pay income tax), and with the Central Transport Licensing Authority (which issues the licences for passenger transport). While the Dar es Salaam City Commission ( I 998) reported a total of 4,OI 2 compliant vehicles, only 3,029 private operators are registered as paying income tax, ${ }^{8}$ and only 3,30 I daladala are recorded as having being issued a licence by the CTLA ( I 998). These divergent figures suggest that operators comply with some of the state regulations, whilst ignoring others. The choice between formality and informality seems to depend on entrepreneurs' individual evaluation of the comparative costs of legality and illegality, rather than on their perception of the legitimacy of the government prescription. If, for instance, a newspaper publicises that the Traffic Police have been given the order to impound vehicles not paying the income tax, as in fact happened on I 2 March i 996 (Daily News i 2.3. I996), then the potential cost of illegality will be perceived to have increased and more operators will elect to comply with this legal requirement.

Beyond differences in the payment of registration fees and taxes, private and pirate operators share a general disregard for the requirements of the safety regulations governing the operation of buses. Non-compliance with road safety rules is clearly related to the oversupply of the market brought about by its deregulation. The existence of an oversupplied market can be deduced from the fact that private operators were forced to decrease fares in order to remain in the competition soon after the state abolished controls on the tariff. Within one week of government announcements on the liberalisation of tariff controls, a local newspaper reported that some daladala operators had reduced fares from I 50 shillings to I oo shillings (Majira 8. I. I997), and it was observed during fieldwork that on most routes a fare of I 50 shillings was charged only at peak times of the day, while the offpeak fare was fixed at ioo shillings. The tariff war that broke out on some routes was not the only form of competition evident among private operators. The overloading of vehicles, divergence from allocated routes, and speeding were practices deemed to be commercially necessary by many operators in order to maintain a competitive edge in a very congested market. It is worth remarking 
that the market seems to remain under conditions close to classical perfect competition. There is no evidence of the emergence of groups of entrepreneurs able to take advantage of their economic or political power to squeeze out less competitive operators.

In a study of the taxi industry in three South African townships, Xhosa (I992) has shown that saturation of the market, over-speeding and the overloading of vehicles were the outcome of the deregulation of the service. Xhosa reports that mafia-type gangs divided up and controlled access to taxi routes in these townships, using guns and violence to effectively enforce restrictions on other operators. While no such pattern of serious criminality is evident in the case of Dar es Salaam, perfect competition amongst private operators does have other social costs. In I 992, $93 \%$ of all fatal accidents in Dar es Salaam involved daladala (Daily Neres i 7.5. I 994). The use of the word 'accident' seems inadequate because it implies an assumption of casualness which does not explain the reality of the behaviour of many private operators. The need for excessive speed is witnessed also by the names given to some of the vehicles by their owners or crew. This naming of vehicles, which reveals something of the informal actors' perceptions of the environment in which they operate, is worthy of some attention. One daladala is named Zig-Zag, implying the skill of its driver in overtaking other buses; another is Dawa ya moto ni moto ['If you speed I speed', but more literally 'the medicine for the gas is the gas']; another is named Usipotambaa mswaki ['If you do not run you will be a brush'], brush being the slang word identifying a bus which 'sweeps the road' without any passengers inside. Another bus has a drawing of two wrestling fighters face to face with the words: 'Warning: no ring, no rules, no referee'. Another is named Mbele kwa mbele ['Always ahead'], echoing the daily challenge in the race track that is Dar es Salaam's municipal road system. A final example is a bus named Utamaliza kuni kwa kuchemsha mawe [literally 'You will burn the whole log to boil stones'], meaning that there is no point in trying to overtake me because you will be no more successful than if you try to boil stones. These names, and many others, suggest that a culture of non-compliance is indeed widely pervasive and deeply rooted in city life, a body of rumours, gossip, satire and new Swahili words witnessing, as Tripp (1997: I 79) has put it, 'the gap between party policy and popular sentiments'. However, it is striking that this culture of non-compliance should have survived long after the deregulation and privatisation of the market. Furthermore, the culture of non-compliance expressed through daladala names most often refers to the laws governing speed limits, which 
cannot reasonably be considered an unnecessary state regulation whose change is long overdue. It has to be acknowledged that the necessity of speeding is not shared by all private operators. One daladala severely condemns the habit of over-speeding by the phrase, Huo ni utoto tu ['That is only infantile'], and another adds Akikuwa ataacha ['When he grows up, he will stop it']. Another vehicle named Shame Less stresses its difference from the majority of private operators. The same message is given by the buses, Mwenda pole ['It goes slowly'] and Tuliza ball ['Control the ball', invoking a popular footballing metaphor].

These antithetic attitudes of daladala workers towards the speed limit derive from fundamental differences in conditions of employment within the labour force. The analysis of the daladala labour market is, in turn, fundamental to an understanding of private sector performance and the social cost of the invisible hand of the market. Although we know the approximate number of buses operating within the market, the number of daladala employees is more difficult to quantify. Neither the Ministry of Communication and Transport nor the Ministry of Labour holds any statistical information on the daladala workforce. However, as we know there to have been between 6,300 and 7,648 daladala operating in I 998, including both licensed and pirate operators, it is possible to take the mean of these estimates $(6,974)$, and calculate the size of the workforce based on the number of persons employed for each bus in operation. The number of workers per bus varies from two (driver and conductor) employed on small buses (vehicles transporting up to twenty passengers), to three (driver and two conductors) employed on larger buses. Based upon the results of a questionnaire (Appendix) distributed among bus workers, and which received 668 responses, it can be estimated that $44 \%$ of buses are of the smaller 'twoman' type, while $56 \%$ are the larger 'three-man' type. On this basis, the labour force employed in the daladala sector can be calculated at about i 7,800 workers.

The sample of 668 workers who responded to the questionnaire therefore comprises about $3.75 \%$ of the total workforce. While the results of this random sample must be treated with caution, it still reveals much of interest about the functioning of the labour market in response to privatisation and deregulation. The daladala employees were asked about the characteristics of the working day (i.e. hours per day, days per week, pay per day or per month), and the nature of the relationship between employers and employees (i.e. the use of contracts, kinship or other links between employer and employees). Rather surprisingly, given the emphasis often placed upon the role of kinship 
in urban labour recruitment in eastern Africa, the results show that $90.7 \%$ of those workers sampled had an exclusively professional relationship with their employer, while only $7.6 \%$ defined the employer as a 'relative', and I.7\% as a 'friend'. Less surprisingly, only I $7.1 \%$ of the sample were employed with a contract, while the remaining $82.9 \%$ were employed without contract. Taken together, these findings strongly suggest that a large majority of workers in the transport system labour market are employed on a casual basis, and that commercial relations predominate in defining the terms of their employment. This implies that in the Dar es Salaam transport system a substantial number of informal actors constitute an exception to the orthodox view of the informal sector as composed of firms where there is 'little or no division between labour and capital' (ILO I993: 43), or 'as home based or individual enterprises with few or no employees' (UNDP: 5 ). The distinctive feature of the daladala labour market seems to be the existence of a class of bus owners whose interests are distinct from the class of casual workers whom they employ. This poses analytical difficulties for those, such as Tripp (1997: 136), who write about 'the conflict between the government and those involved in the informal economy', as it risks overlooking the importance of power relations within the informal sector itself. As will now be demonstrated, conflicts of interest between workers and their employers are a crucial dynamic of the political economy of the daladala sector.

The relative ease of entry into the urban transport labour market has a significant impact on the terms of employment. The low level of educational requirements for daladala workers is common knowledge in Dar es Salaam, as indicated in this ironic advert quoted from a whimsical Swahili article by a local journalist (Majira i8. I.1998):

Daladala conductor wanted. He has to have studied until the seventh level, if not until the fourth level. If not provided with a fourth level class, he has to be able to count money and to give back to the passengers the right change.

The irony encompasses the fundamental fact that any man can become a daladala conductor. The qualifications necessary to become a daladala driver apparently present a greater challenge, with an initial capital of 50,000 shillings being needed to acquire a driving licence. However, fake driving licences can be easily bought in Dar es Salaam for onetenth of this sum. The ease of access to the market results in its oversupply, and this in turn weakens the position of employees. Of those workers questioned, $82.9 \%$ were employed not only without a written contract, but without a fixed wage. In a strict sense, workers are not 
'waged'; rather they operate the bus each day as a kind of franchise, for which they must pay a fixed daily fee. ${ }^{9}$ The exploitative nature of employer/employee relations is therefore not formalised in any 'agreement' on the workers' wages or conditions of service in the workplace, but lies in the cost set upon the franchise each day. In theory, this fee is negotiable. In practice, the scope that employees have to bargain is severely curtailed by the nature of the labour market. A driver temporarily 'on the bench' (note, again, the use of a football metaphor) explained the predicament to me in graphic terms (Mashaka i 998):

As too many of us are jobless, if for instance a bus owner is looking for a driver, he will find more than fifty people just at this station [i.e. Mwenge station]. That is why they can ask you whatever they want and you have to accept it. I have been working with the same bus for two years. He used to ask me for 50,0oo shillings every day. Since then the buses have become too many and the chance of making money has decreased. I went to my employer and I told him 50,000 was not possible anymore. He could not understand me and he wanted his bus keys back. He gave the bus to somebody else and he is still working with it. I do not know if he manages to give him back 50,ooo every day.

In these circumstances, bus owners can 'squeeze' the fees charged to employees upwards, so that in order to maintain a stable level of income, drivers and conductors are pressed to make a greater number of journeys and to carry more passengers. The magnitude of the worker's daily return must inevitably depend on these two factors. The number of journeys per day is determined by the speed of the driver in negotiating the city traffic, and the number of hours of daily work. The principal limiting factor on the length of the working day is the demand for transportation, a fact confirmed in uniform responses to the questionnaire indicating that the average working day lasts i 5 hours. If the working day is fixed by diminishing demand, then speed of travel remains the crucial variable. Under these circumstances, as another driver explained, the link between workers' exploitation and the high number of road accidents becomes clear (Ramadhan I998):

My owner wants $30,0^{000^{10}}$ shillings every day. If I drive without speeding I will work for the whole day to gain only the money the owner wants back at the end of the day. For these reasons we are forced to speed from 5 a.m. to 9 p.m. Then they say too many accidents, how much energy should we have?

To maximise the return on each trip, drivers therefore speed. Conductors contribute to maximise the margin by cramming in as 
TAB LE 6

Trends in student and adult tariff $1983-$ I 996

\begin{tabular}{|c|c|c|c|c|c|c|c|c|c|c|}
\hline $\begin{array}{l}\text { Date of review } \\
\text { of the tariff }\end{array}$ & $\begin{array}{l}8.7 . \\
\text { I } 983\end{array}$ & $\begin{array}{l}\text { I0.4. } \\
\text { I } 988\end{array}$ & $\begin{array}{l}6.9 . \\
\text { I } 989\end{array}$ & $\begin{array}{l}2.2 . \\
\mathrm{I} 99 \mathrm{I}\end{array}$ & $\begin{array}{l}\text { 4. I I. } \\
\text { I } 99 \text { I }\end{array}$ & $\begin{array}{l}17.5 . \\
1992\end{array}$ & $\begin{array}{l}\text { 8. Io. } \\
\text { I } 993\end{array}$ & $\begin{array}{l}7.8 . \\
\text { I } 994\end{array}$ & $\begin{array}{l}7 \cdot \mathrm{I} \\
\mathrm{I} 995\end{array}$ & $\begin{array}{r}20.12 . \\
1996\end{array}$ \\
\hline Adults & 5 & 6 & 8 & I 5 & 30 & $3^{0}$ & $5^{\circ}$ & 70 & IOO & I $5^{\circ}$ \\
\hline Students & I & I & I & 5 & 5 & I 5 & 20 & 20 & 30 & $5^{0}$ \\
\hline
\end{tabular}

Sources: Shirika la Usafiri Dar es Salaam r994: 24; Daily Newes 8.r.i 995, 3I.I 2.I 996.

many passengers as possible. This strategy implies that the vehicles will be systematically overloaded, but it also means that conductors will seek to maximise the return on each trip. Similarly, attempts to assign daladala to specific routes, in order to provide a public service, may be ignored by drivers if the returns obtained from operating on quieter, less busy routes are perceived to be too low. With these factors in mind, it becomes clear that many of the inefficiencies characterising the Dar es Salaam transport system are, in fact, a consequence of the exploitative conditions of employment governing the earning capacity of employees. In reacting to these conditions, workers' engage in systematic violations of safety rules and regulations whose compliance should be the goal of any well-managed passenger transport system.

Another important consequence of the exploitative relations of production between bus owners and workers is the daily conflict between workers and the beneficiaries of the welfare state. A useful case to illustrate the social conflict generated by the withdrawal of the government from transport provision is the history of the difficult relationship between daladala workers and students. The tariff policy of the government towards the students up until the early ig8os reflects how the social function of the service was then given priority over company profit. In I 983 , when private operators entered the transport system, the government still retained power to determine tariffs, and attempted to compel private operators to adopt the privileged tariff conceded to students. Tariffs were controlled by the government until I996, and between I983 and I996 students formally retained the privilege of a 'social' fare on all daladala routes in the city. Over this period the ratio of student to ordinary adult tariffs fluctuated from I : 8 in 1989 to I : 2 in I 992 . Even at their lowest level of social protection, students were accordingly paying half the tariff charged to adult passengers. 
Given the characteristics of the franchise system operating in the transport labour market, it will be clear that the burden of the state's welfare policy towards students fell squarely upon the daladala workers. The state has at no time subsidised the economic loss incurred by bus owners for the transportation of students; nor do workers receive a discount from owners on the amount of money they are asked for at the end of the working day in relation to the numbers of students transported. The arena of conflict between the two parties is thus clearly defined: students are entitled to concessionary tariffs on any daladala journey, but conductors can only grant those concessions at a cost to their own income. Not surprisingly, clashes between daladala workers and students have become a common feature of the Dar es Salaam transport system, with incidents frequently being reported in the press. During the 'Day of the African Child' in r 99 I, for example, a delegation of children urged President Mwinyi 'to offer them protection against daladala bus operators' (Daily News i8.6.i99 I). As local reports reiterate, it is a conflict with victims on both sides. ${ }^{11}$ Daladala workers have been taken before the courts and fined (Daily News 25.7.1992; Uhuru i r.6.i994; Majira 24.9.1994), while in r 992 a delegation of workers met with the minister of home affairs to find a solution to the abuses suffered by drivers and conductors as a result of the students (Daily News io.3.1992). Government officials have threatened to withdraw licences from operators for failure to comply with student tariffs, and the actual withdrawal of licences has been reported (Daily News 27.7.I99I, 6.3.I992, 23.03.I993, 24.3.I995; Nipashe 30.3. I995). Police have also been called to defend students from harassment by bus crews, when they had protested over fares (Daily News i i.o8. I992, I 4.08.1996).

Attempts have been made to reconcile this conflict by imposing limits on the number of students that may be carried by buses on each journey. Until i993, government regulations stipulated that small buses should carry a limit of five students per trip, and larger buses up to ten students. But on 26 May i 993 , the minister of home affairs announced that this was proving insufficient to meet demand, and that daladala would be compelled to transport an unlimited number of students until 7.30 a.m. each morning, so that they could attend school on time (Uhuru 27.5.I993). In response to this government decree, no private buses appeared on the roads of Dar es Salaam the following day until after 7.30 a.m (Daily News 28.5. I 993), ${ }^{12}$ vividly demonstrating the incapacity of the state to enforce its own regulatory devices. It is also apparent that the state itself is divided over the emphasis to be given 
in public policy in this area, with different ministries holding conflicting views. In November i 998, for example, a press release from the Ministry of Communication and Transport (1998) sought to better protect daladala workers and reverse the intentions of the minister of home affairs, by prescribing that 'small buses should carry three students per trip, big buses five'. In practice, none of these interventions has proved effective. The main cause of conflict between students and private bus workers is that workers are asked to pay the price of students' protection, and this has not been tackled by government. Moreover, the public perceive that the government now lacks the capacity to intervene successfully. As one daladala worker joked, 'they [the government] are strong like Coca-cola' (Airi r998); and, as everyone knows, Coca-cola is a soft drink.

THE DALADALA OWNERS' ASSOGIATION

In place of over-idealised conceptions about their supposed universal benefits, the privatisation and deregulation of the Dar es Salaam transport system has led to the emergence of sharp conflicts, both between employees and employers, and between workers and students, fiercely competing over the distribution of the costs and benefits of the market. How successfully have the daladala owners adapted to these new conditions? Nominally, Dar es Salaam's private bus owners have an association-MUWADA (Muungano wa watu wanaosafirisha daladala - to defend their commercial interests in these struggles. The association was formed in 1983 , only some two weeks after the decision that allowed private buses to operate legally in Dar es Salaam. MUWADA was founded on the initiative of a daladala owner, Ghalim Kassim Dibbu, who brought together a group of private urban transport entrepreneurs to cope with the various problems emerging in running their businesses (Uhuru I6.4.1983). This group of daladala entrepreneurs drew up the association statute, and then submitted their proposed constitution to UDA which scrutinised the document to establish 'its compliance with the founding principles of the nation' (Uhuru 30.05. I983). Having been judged to be in keeping with national policy on 'associationism', the statute was approved five months later, in May I 983 . What this meant, in practical terms, was that MUWADA had been accepted as legitimately representing the interests of all those within the sector, and as such was officially recognised as 'the only association of daladala owners in Dar es Salaam’ (MUWADA I983:3). 
In this sense, it is significant to note that the opening of urban transport provision to private operators did not then imply a formal revision of the principles behind ujamaa. MUWADA was not to be a voluntary association of daladala owners at this stage; rather, membership was to be a compulsory requirement for all of those who wished to operate private bus services within Dar es Salaam. The statute of MUWADA in fact represented one of the last enforcements of this corporative principle. In i 984 , the Tanzanian parliament formally recognised freedom of association as a principle granted under constitutional law (URT i 998: 24). This had the effect of making MUWADA's original statute unconstitutional, but, as we shall see, in practice the government continued to treat MUWADA as if no such change had taken place.

Apart from the two newspaper articles documenting the date of foundation and the modalities of the statute approval, little was heard of MUWADA over the next few years. A study funded by the World Bank, to improve urban passenger transport in Dar es Salaam, even claimed that 'the association of private operators, formed when private buses were legalised, has since become inactive' (Wilbur Smith Associates I99 I : 5). This perception changed dramatically from I99 I, since when MUWADA's activities have been constantly reported in the local press. The new activism coincided with a change in the leadership of the association, George Ndaombwa being elected as president early in i99 I (Ndaombwa I998).

A few months after Ndaombwa's election, the minister of home affairs, Mrema, announced that all daladala drivers and conductors were to wear blue uniforms with badges for ease of identification (Daily News 28.6.I99I). The measure was aimed 'at restoring discipline of daladala crew and reducing the rising number of traffic offences' which were then considered to be reaching 'alarming proportions' (ibid.). Although the daladala crews were predictably slow to take up this initiative, and the declaration had to be reissued in an attempt to encourage compliance (Mtanzania 26.6. 1998), the measure was actively supported by MUWADA. The reason for this support was that MUWADA had been granted a monopoly of the making and selling of badges, from which the association was able to draw an important source of income. The status of the organisation was further reinforced by government during I 993, when the minister of communication and transport announced that 'owners of daladala would not be given licences unless they joined MUWADA', at the same time declaring MUWADA to be 'the only recognised organ which would help the Government in solving daladala problems' (Daily News i 3.2.I 993). This 
ministerial statement was an endorsement of the position stated in MUWADA's pre-I984 statute, but ignored the changes made during I 984 to Tanzanian law on freedom of association. Whatever the correct legal position may have been, by September press reports documented vehicles actually impounded for not carrying MUWADA badges (Daily News I8.og. I993), and daladala operators were under pressure to comply with the decree. Having been founded as an association of private operators of daladala, MUWADA has become an association profiting from private operators. In practice, it is now the duty of private operators to prove they have joined MUWADA, the proof being the display of an association sticker, which is nowadays sold at the price of 3,700 shillings and is valid for one year.

How, then, have the bus owners reacted to this costly imposition? The economic reality is more ambiguous than it may at first seem. Stickers are sold by MUWADA without any reference to the legal status of the bus. In other words, both private and pirate buses are potential purchasers of the sticker. Therefore, among those buses carrying the MUWADA sticker may be many that have not complied with other legal requirements of registration. Whether an owner chooses to purchase a MUWADA sticker or not will depend on a number of related issues, but owners can broadly be grouped in three categories. In the first category are owners who have rejected the MUWADA sticker as an unnecessary and illegitimate imposition. However, as a daladala worker explains, the burden of this decision inevitably falls on the workers (Baghdadi i 998):

When I told my employer that we are requested the sticker of MUWADA, he told us that MUWADA and daladala are two different things. They cannot force you to join the association and therefore the sticker is not necessary. The police, they have a different story. They stop you and ask where the sticker is. If you say that they cannot force one to join MUWADA they answer that it is not true and they want to take the bus to the police station. But we cannot go to the police station because at the end of the day the bus owner wants his money and does not care about MUWADA, the police or anything else. So we workers give a little something to the police and we go back to work.

In contrast, a second category of daladala entrepreneur opts for noncompliance while personally paying the cost of his decision. In this case, the buses are operated by kin, often by sons, and so the owner is prepared himself to carry the costs of these 'extras'. As one daladala owner explained (Omari I998):

Badges, stickers, uniforms and so on, these are all useless things. They invent one after another and it is expensive and a waste of time to follow them. We 
PRIVATISATION OF DAR ES SALAAM TRANSPORT SYSTEM I53

count amongst the management costs that constantly you have to give a little to the police and at least we do not have to go every now and then to MUWADA.

Lastly, there is a third group of entrepreneurs who refuse to purchase the sticker, and who also refuse to shift the costs onto their workers. People belonging to this group obviously do not need MUWADA to defend their interests (Maiko I998):

We can work without MUWADA badge because of our employer. He is very well known; he has owned daladala for a long time. So if the police stop us and we start showing them the bus documents, they will understand that they have stopped the bus of our employer, and he is well known, respected ... We do not worry about these things.

If MUWADA can be seen to have become a direct burden upon private bus owners, it must be acknowledged that it has conspicuously failed in its efforts to mobilise in their interests in other respects also. This is most evident in discussion of tariffs, where MUWADA has consistently campaigned for raising fares (Uhuru 5. Io.r 993). However, while MUWADA's president has been calling for fares to rise by up to $300 \%$ (Majira i I.I I.r 1994), the government's deregulation of the fare structure in 1996 in fact led to a downward trend in tariffs. Therefore, as an overall conclusion on the influence of the 'informal political sector' in the defence of the interests of bus owners, MUWADA seems to be an institution that is singularly ineffective in influencing the government's policies, but effective as a private rent-seeking institution.

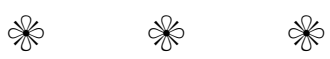

The positive consequence of the change from state monopoly to a privatised and deregulated bus service in Dar es Salaam has been most evident on the supply side. Since the early 'nineties, following fifteen years characterised by transport shortages, Dar es Salaam's private buses have managed to meet the demand for transport. Given what is known about the small scale of most enterprises operating within the daladala sector, it is relevant to ask where all the additional buses came from to so expand the market, and how their purchase was financed. It should be understood which entrepreneurs have taken advantage of newly available investment opportunities as the Tanzanian financial sector liberalised; and whether privatisation has indeed drawn new 
investors into the daladala business, thus broadening the ownership of assets. Regrettably, the process of licence registration does not make it possible to identify specific investors in each daladala business, and so the extent of these processes must for now remain a matter of speculation. But, in understanding the constraints and opportunities operating in the transport sector as a consequence of deregulation, it would clearly be important to know more about investment and return for those funding bus purchases.

On the other hand, it can be argued that the transport market in Dar es Salaam is now over-supplied, and that this in part derives from a lack of state control over conditions of entry to that market and regulation of standards within the market. Competition between an excessive number of private operators has manifested itself in speeding, overloading of vehicles, and reluctance to comply with public policy directives on concessionary tariffs. The findings of this study suggest that these failings can best be explained by the nature of the exploitative labour relations prevailing within the daladala sector, conditions of service that apply equally to those buses legally registered and to pirate operators who lack the required registrations. A lack of effective regulation on working conditions allows bus owners to take advantage of the oversupply of the labour market to protect their own margins of profit at the cost of their workers and/or passengers. Long working days and no security of employment are imposed on a mass of casual workers in the private sector. Their attempt to make the best out of a difficult situation in turn threatens the safety of all passengers through speeding and overloading. This conclusion stands in sharp contradiction to the pronouncements of the World Bank on labour legislation in SSA. While the World Bank (I995: I7) asserts that 'regardless of the intention of such direct interventions in labour markets, the legacy has not been positive', this article has demonstrated the social cost of informality in Dar es Salaam's transport labour market. A state acting for the protection of workers, and perhaps increased investment in infrastructure, seems the only likely solution to the problems evident in Dar es Salaam's deregulated transport system. 
PRIVATISATION OF DAR ES SALAAM TRANSPORT SYSTEM I55

APPENDIX: QUESTIONNAIRE AND SUMMARY OF RESULTS ${ }^{1}$

2. (a) Dereva (Driver)

(b) Kondakta (Conductor)

3. Tangu lini umeanza kufanya shuguli za daladala?

Since when have you been working with private buses?

4. Umeshafanya kazi kwenye daladala ngapi?

How many daladala have you worked on?

5. Umeajiriwa kama (Are you employed):

(a) mkataba? (with contract?)

(b) kibarua? (without contract?)

6. Unafanya kazi kwenye (Which make of bus do you work with?) $)^{3}$ :

(a) Toyota Hiace

(b) Isuzu Coaster

(c) Toyota DCM

7. Kwa mwezi unalipwa kiasi gani? (What is your monthly wage?) 34,672 shillings

Kwa siku posho kiasi gani unapata? (What is your daily income?) $67.6 \%$ answers "it depends"

$32.4 \%$ answers, average 2,654 shillings

8. Kwa wiki unafanya kazi siku ngapi? (How many days per week do you work?) $\quad 6.67$

9. Kwa siku masaa mangapi ya kazi? (How many hours per day?)

I. 56 daladala/year ${ }^{2}$

o. Uhusiano gani na mwenye gari? (What is your relationship with the owner of the bus?)

(a) Jamaa (Relative) $\quad 7.8 \%$

(b) Rafiki (Friend) $1.7 \%$

(c) Mwenye gari tu (Purely business) $\quad 90.7 \%$

1 This questionnaire was completed by a sample of 668 workers.

2 This figure is the ratio between the mean of question 3 and that of question 4 .

3 This question aimed to estimate the total number of daladala employees. This was possible as both (b) and (c) employ three workers (one driver and two conductors) while (a), small bus for up to 20 people, employs only two workers.

\section{NOTES}

I. This paper is based on three months fieldwork carried out in Dar es Salaam between September and December i 998, for my dissertation at the Istituto Universitario Orientale, Naples (Italy), during which period interviews and a questionnaire were conducted in the city with bus workers and owners, and documentary and newspaper sources were consulted at various ministries and libraries. A short research report has been published in Italian (Rizzo I 999).

2. For evidence from South Africa on the limits of privatisation and deregulation in the urban transport sector, see Xhosa i992, McCaul i99o. On the limits of the deregulation in the Tanzanian agricultural sector see Bryceson i993; Havnevik I993: 287-3 I3; Putterman i 995.

3. UDA fleet repair was further complicated by the presence of five different bus types (Godard \& Turnier i 992: 53), deriving from four different aid programmes funded, respectively, by Hungary, Japan, the United Kingdom and the Federal Republic of Germany (Wilbur Smith Associates I99 I : $3-4)$.

4. For the impact of state crisis on Dar es Salaam City Council capacity to maintain a road system in good condition, see Kulaba I 989 : 240.

5. The name daladala comes from the name of the 5 shilling coin used to pay for a trip in I $9^{8} 3$. As 5 shillings was equivalent to $\$ \mathrm{I}$, dala was the Swahilisation of dollar.

6. Since r 99 I estimates have been obtained by keeping the I 99 I private/pirate ratio constant. 7. The East African, 2 I.7. I999, accessed at

< http://www.nationaudio.com/News/EastAfrican/ I90799/Regional/Regionalı.html >

8. The Tanzania Revenue Authority does not keep a centralised record of the data. The figure 
of 3,029 is obtained by the sum of the operators registered by Ilala District (I,254), Kinondoni District ( I,058) and Temeke District (7 I 7) (TRA I998a, b, c).

9. For evidence of the identical labour relationship in the Kinshasa transport system, see Pain I984: I 74, quoted in Stren I988: 233.

Io. As the reader will have noted, this figure differs substantially from the previous one However, what differs is the size of the bus operated, not the amount of work demanded.

I I. See Daily Neres 5.5. I 993, reporting on a conductor beaten to death by a group of students.

I2. It is worth underlining the changing nature of social conflict in the transport system. In the early eighties, as Tripp (I997: I) reports, people's notion of justice spontaneously united them to contest the legitimacy of the banning of private buses: 'A group of about forty Dar es Salaam passengers had boarded a privately owned daladala minibus to go to work. On their way they were stopped by a police officer. ... Realising they would be in trouble, the passengers, who up until that moment had been perfect strangers, spontaneously transformed themselves into one big, happy family on its way to a wedding and started singing, clapping, and making shrill, ululating sounds, as is the custom for people on their way to celebrations. The police, unable to charge the driver for operating a bus on a commercial basis, had no choice but to let them go.' Ten years later people's notion of justice has been replaced by competing interests embodying different notions of justice, as daladala workers' spontaneous refusal to transport students shows.

\section{REFERENGES}

Adam, C., W. Cavendish \& P. S. Mistry. 1992. Adjusting Privatisation: case studies from developing countries. London: James Currey.

Baregu, M. 1993. 'The economic origins of political liberalisation and future prospects', in M. S. D. Bagachwa \& A. V. Y. Mbelle, eds., Economic Policy Under a Multiparty System in Tanzania. Dar es Salaam: Dar es Salaam University Press, I05-23.

Bennell, P. I997. 'Privatization in Sub-Saharan Africa: progress and prospects during the i99os', World Development 25, i I : i 785-803.

Berg, E. 1996. 'Privatization in Sub-Saharan Africa: results, prospects and new approaches', in P. Paulson, ed., The Transition from African Socialism. London: Macmillan.

Bryceson, D. F. I993. Liberalizing Tanzania's Food Trade. London: James Currey.

Bureau of Statistics. I 989. I980 Population Census: Preliminary Report. Dar es Salaam: Ministry of Finance, Planning and Economic Affairs.

Campbell-White, O. \& A. Bhatia. 1998. Privatisation in Africa. Washington, DC: World Bank.

Central Transport Licensing Authority (CTLA). Various years. 'Microbuses file' (files from I $994 / 95$ to $1997 / 98$ accessed at UDA).

Cramer, C. 2000. 'Privatisation and adjustment in Mozambique: a 'Hospital Pass'?', Fournal of Southern African Studies 27, I: 79-104.

Dar es Salaam City Commission. i998. ' 1998 Microbuses file'.

Europa. I 999. Africa South of Sahara 1999. London: Europa Publications.

Godard, X. \& P. Turnier. 1992. Les transports urbains en Afrique à l'heure de l'ajustement: redéfinir le service public. Paris: Karthala.

Havnevik, K.J. i993. Tanzania: the limits to development from above. Uppsala: Nordiska Afrikainstitutet.

International Labour Organisation. I993. 'International Conference of Labour Statisticans. Resolution II', in P. E. Bangasser, 2000. The ILO and the Informal Sector: an institutional history. Geneva: ILO, 4 ${ }^{\mathrm{I}-55}$.

International Monetary Fund. i 999. Tanzania: recent economic developments. Washington, DC: International Monetary Fund Country Report No. 99/24.

Kulaba, S. I 989. 'Local government and the management of urban services', in R. Stren \& R. R. White, eds., African Cities in Crisis: managing rapid urban growth. Boulder, CO: Westview, 203-46.

Maliyamkono, T. L. \& M. S. D. Bagachwa. 1990. The Second Economy in Tanzania. London: James Currey.

Mamuya, I. 1993. Structural Adjustment and the Reform of the Public Sector Control System in Tanzania. Hamburg: Institut für Afrika-Kunde.

McCaul, C. I990. No Easy Ride: the rise and future of the black taxi industry. Johannesburg: South African Institute of Race Relations.

Ministry of Communication and Transport (MCT). I987. 'Proposed national transport policy'. Dar es Salaam. 
PRIVATISATION OF DAR ES SALAAM TRANSPORT SYSTEM I57

Ministry of Communication and Transport (MCT). 1998. 'Press release of the official meeting about students' harassment by daladala operators'. Dar es Salaam, released 30 November.

MUWADA. I983. 'Katiba ya MUWADA' (unpublished statute).

O'Connor, A. I 988 . 'The rate of urbanisation in Tanzania in the I970s', in M. Hood, ed. Tanzania after Nyerere. London: Pinter, I $36-42$.

Pain, M. I984. Kinshasa: la ville et la cité. Paris: ORSTOM.

Putterman, L. I 995. 'Economic reform and smallholder agriculture in Tanzania: a discussion of recent market liberalization, road rehabilitation, and technology dissemination efforts', World Development 23, 2: 31 I-26.

Rizzo, M. I999. 'Stato, economia informale e società civile: il caso del sistema di trasporto urbano a Dar es Salaam', Afriche e Orienti 4: 54-6I.

Shirika la Usafiri Dar es Salaam (UDA). r994. 'Five Year Development Plan'.

Shirika la Usafiri Dar es Salaam (UDA). I 995 . 'Maelezo mafupi kuhusu UDA na shuguli zake yasiyowasolishwa kwa mheshimiwa Dr. Maua Daftari Mbunge Naibu Waziri wa Mawasiliano na Uchukuzi alipotembelea UDA 2 I.I2.I995' (A short report on the performance of UDA, presented by Dr Maua, Vice-Minister of Communication and Transport, on the occasion of his visit to UDA).

Shirika la Usafiri Dar es Salaam (UDA). Various years. 'Fleet performance files' (files from I $994 / 95$ to $1997 / 98)$.

Stren, R. I 988 . 'Urban services in Africa: public management or privatisation?', in P. Cook \& C. Kirkpatrick eds., Privatisation in Less Developed Countries. Brighton: Wheatsheaf.

Stren, R. I989. 'The administration of urban services', in R. Stren \& R. R. White, eds., African Cities in Crisis: managing rapid urban growth. Boulder, CO: Westview, 37-68.

Tanzania Revenue Authority (TRA). I998a. 'Daladala files'(files on District of Ilala).

Tanzania Revenue Authority (TRA). I998b. 'Daladala files' (files on District of Kinondoni).

Tanzania Revenue Authority (TRA). I998c. 'Daladala files' (files on District of Temeke).

Temu, A. E. \& J. M. Due. 200o. 'The business environment in Tanzania after socialism: challenges of reforming banks, parastatals, taxation and the civil service', Fournal of Modern African Studies 38, 4: 683-71 2.

Tripp, A. M. 1997. Changing the Rules: the politics of liberalisation and the urban informal economy in Tanzania. Berkeley, CA: University of California Press.

UDA, see Shirika la Usafiri Dar es Salaam.

United Nations. 1996. Informal Sector Development in Africa. New York: United Nations Department for Policy Coordination and Sustainable Development.

United Nation Development Programme (UNDP). Year missing. Supporting Informal Sector Activities. New York, quoted in United Nations. I 996.

United Republic of Tanzania (URT). I974. 'Exclusive licence granted to Shirika la Usafiri Dar es Salaam to operate passenger services in Dar es Salaam' (unpublished licence, i 9 January).

United Republic of Tanzania (URT). I998. The Constitution of the United Republic of Tanzania. Dar es Salaam: MPP.

Wilbur Smith Associates. I99I. 'Dar es Salaam urban passenger transport study' (unpublished consultancy).

Xhosa, M. г992. 'Routes, ranks and rebels: feuding in the taxi revolution', Fournal of Southern African Studies I8, I : 232-5I.

World Bank. 1995. Labour and the Growth Crisis in Sub-Saharan Africa: regional perspectives on World Development Report 1995. Washington, DC: World Bank.

\section{Interviews}

Airi, driver, Dar es Salaam (Masaki), i 8 December i 998.

Baghdadi, driver, Dar es Salaam (Posta Mpya), i 5 December 1998.

Maiko, Dar es Salaam (Posta Mpya), i5 December i 998.

Mashaka, driver Dar es Salaam (Mwenge), io December i 998

Mr Mlaki, Operations manager UDA, Dar es Salaam (Kurasini), I 5 November I 998.

George Ndaombwa, Chairman of MUWADA, Dar es Salaam (Kisutu), 20 December I 998.

Omari, bus owner, Dar es Salaam (Ubungo), i 7 December i 998.

Ramadhan, driver, Dar es Salaam (Kariakoo), 8 December 1998.

Newspapers (all published in Dar es Salaam)

The African; Alasiri; Daily News; Dar Leo; The Guardian; Majira; Mtanzania; Nipashe; Uhuru. 